https://nv.nltu.edu.ua

https://doi.org/10.36930/40300212

Article received $23.03 .2020 \mathrm{p}$.

Article accepted 04.06.2020 p.

$@ \square$ Correspondence author

O. B. Salovskyi

UDC 330.341 .2

Львівський національний університету ім. Івана Франка, м. Львів, Україна

\title{
ДЕРЖАВНА ПОЛІТИКА РЕФОРМУВАННЯ ІНСТИТУЦІЙНОЇ СИСТЕМИ УКРАЇНИ
}

Проаналізовано еволюцію державного впливу на розвиток інституцій у вітчизняній господарській системі. Наголошено на проблемах систематичної незавершеності та пролонгації реформ у часі, а також недостатньо помітної результативності державної політики, причини яких криються у царині інституцій. Дослідження побудовано на підставі сформульованого автором підходу до аналізу української господарської системи з акцентами на інституціях власності, влади, конкуренції, інновацій та цінностей. Охарактеризовано риси державного регулювання відносин власності в Україні, зазначено інституційні вади процесу приватизації. Виокремлено позитивні аспекти реформування державних підприємств та загрози, пов'язані 3 концентрацією власності в руках фінансово-промислових груп. Окреслено динаміку політичного клімату та наголошено на несистематичності реформ у сфері влади, державної служби та боротьби з корупцією, а також їх протидії з боку окремих елементів політикуму; з'ясовано головні досягнення та ризики децентралізації влади. Визначено особливості державної конкурентної політики, підкреслено формалізовану спрямованість демонополізаційних зусиль; описано проблеми поєднання влади і власності на окремих ринках та пов'язану з цим хвилю нового монополізму і оновлених заходів захисту конкуренції. Проаналізовано специфіку державного інституційного впливу на інноваційне середовище, аргументовано недостатність державної підтримки та декларативність пільг для інноваторів; відзначено схильність до загальної незацікавленості органів влади в успішному стимулюванні інноваційної активності підприємств. Розкрито характер державного впливу на формування цінностей громадян, зокрема через регулювання сфер освіти та культури. Обгрунтовано причини хронічної незавершеності реформ в Україні, окреслено можливі сценарії подальшого руху вітчизняної господарської системи у зв'язку із формуванням державної політики у сфері інституцій.

Ключові слова: формальні інституції; інституційні реформи; влада; власність; конкуренція; інновації; цінності.

Вступ. Зазвичай зважене державне регулювання відіграє важливу роль в еволюції господарських систем, оскільки істотно впливає на процес закріплення формальних інституцій та сприяє їх збалансуванню із неформальними нормами. Загалом ухвалення рішень (зокрема формулювання "правил гри") у межах державного апарату має, зазвичай, стадійну структуру і залучає велику кількість індивідів з різними та не завжди узгодженими інтересами. За умови досягнення суспільно бажаної конфігурації згаданих аспектів господарська система прямує до інституційної рівноваги та задоволення інтересів громадян.

Однак в українських реаліях, з огляду на атмосферу регулярної незавершеності та відтягування реформ у часі, постійного кризового фону та не зовсім втішної макроекономічної динаміки останніх років, зростає актуальність дослідження особливостей позитивного і негативного впливу державної політики на реформування інституцій в Україні та причин ï̈ недостатньо відчутної результативності.

Аналіз літературних джерел. Фундаментальний внесок у розвиток теорій інституційної економіки здійснили відомі вчені Д. Норт, Д. Аджемоглу, Р. Нельсон, Дж.Стігліц, Дж.Ходжсон та ін. Окрім цього, впродовж останніх десятиліть питання реформування державної політики вивчали Дж. Єллен, Дж.Кітчінг,
О. Длугопольський, О. Могильний, А. Стельмащук, Д. Стеченко та ін. Особливості різних аспектів державної політики стосовно інституцій стали предметом досліджень А. Білоус, Л. Жукової, В. Захарченка, В. Іванюти, Т. Гусейнова, Л. Лебедевої, Н. Малініної, Н. Ногінової, В. Савченка, С. Пригородової та ін. Оскільки сучасні публікації у сфері державного регулювання інституцій переважно звертають увагу тільки на окремі ії сфери або тяжіють до виокремлення загальноекономічних закономірностей, нагальним $є$ формулювання комплексних підходів до державної політики щодо інституцій, котрі поєднують позитивні риси обох поглядів на проблему.

Об'єкт дослідження - вітчизняна господарська система в період незалежності (від 1991 р.) у контексті інституційного аналізу.

Предмет дослідження - сукупність економічних, політичних, правових, культурних чинників у сфері власності, влади, конкуренції, інновацій та цінностей, динаміка яких визначає структуру та особливості державної політики щодо інституцій.

Мета дослідження - проаналізувати риси державної політики стосовно інституцій власності, влади, конкуренції, інновацій та цінностей відповідно до сформульованого автором підходу, а також з'ясувати причин складності здійснення успішних реформаційних зусиль

Інформація про автора:

Саловський Остап Богданович, аспірант, кафедра економічної теорії. Email: o.salovskyi@gmail.com; https://orcid.org/0000-0002-2024-9626

Цитування за ДСтУ: Саловський О. Б. Державна політика реформування інституційної системи України. Науковий вісник НЛтУ України. 2020, т. 30, № 2. С. 66-71.

Citation APA: Salovskyi, O. B. (2020). Public policy reforms of institutions system in Ukraine. Scientific Bulletin of UNFU, 30(2), 66-71. 
3 довготерміновим ефектом.

Для досягнення зазначеної мети сформульовано такі основні завдання дослідження:

- визначити ключові засади та результати державного реформування власності у вітчизняній економіці;

- охарактеризувати особливості державного регулювання владних відносин в Україні, зокрема реформи державної служби та децентралізації;

- з'ясувати сутність державного впливу на розвиток конкурентного та інноваційного середовищ, а також формування загальнодержавних цінностей в Україні;

- виокремити чинники, які гальмують процеси здійснення дієвих реформ в українській економіці.

Наукова новизна результатів дослідження полягає в тому, що вперше було досліджено та ідентифіковано актуальні проблеми інституційної системи вітчизняної економіки та в подальшому розробленні концептуального теоретико-методичного підходу до аналізу державного реформування економіки 3 погляду інституцій власності, влади, конкуренції, інновацій та цінностей.

Практична значущчість отриманих результатів полягає у тому, що успішність вітчизняної державної політики щодо інституцій через стійкий симбіоз влади, власності, політично підтримуваного монополізму, популізму, непрозорості, незацікавленості у змінах/інноваціях призводить до того, що державна політика на багато років стала полем битви для інтересів вузьких груп, тоді як суспільні потреби не були на першому місці.

Матеріали та методи досліджсення. Теоретикометодологічною базою дослідження є здобутки економічної теорії, інституційної економіки та державної регуляторної політики. Для реалізації окреслених вище завдань використано загальнонаукові та спеціальні методи. До першої групи відносимо синтез, сходження від абстрактного до конкретного, індукцію та дедукцію, структурно-логічний та історично-еволюційний аналіз. Серед спеціальних методів зазначимо квалітативний (якісний) аналіз та метод "case study". Інформаційною базою дослідження є державні програми, нормативноправові акти, офіційні матеріали державних органів та наукові публікації.

Викладення основного матеріалу. Згідно із раніше викладеним та обгрунтованим автором оригінальним підходом до аналізу трансформаційних і еволюційних процесів в українській господарській системі [12, с. 273], інституції власності, влади, конкуренції, інновацій та цінностей виступають, значною мірою, ключем до розуміння природи іiї інституційних проблем (рисунок). Оскільки за характером відносин власності, влади, конкуренції, інновацій та цінностей Україна знаходиться в стані інституційної нерівноваги, потрібно з'ясувати, що саме та коли визначило хід державної політики реформування інституцій у тій чи іншій сфері. Почнемо із першої складової - власності.

Загалом головні завдання державного регулювання власності у ринковій економіці стосуються надання відповідним відносинам прозорого характеру, раціонального перерозподілу власності, а також захисту прав власності. В Україні "цивілізацію" відносин власності здійснювали паралельно із роботою над створенням розумної структури іiі форм, зокрема процесами приватизації в умовах краху попередньої економічної системи, браку досвіду, конфлікту приватних і суспільних інтересів тощо.

На думку В. Савченка, "рівень нормативно-правового регулювання приватизації державного майна є таким, що призводить до послаблення системи державного регулювання ..., зниження інвестиційної та інноваційної активності, ... ускладнення створення конкурентного середовища, а відтак посилює загрозу національним інтересам" [13, с. 13]. Йдеться переважно про створення окремих фінансово-промислових груп з дещо відмінними від суспільних інтересами, отримання доходів через часткову тінізацію, тривалу відсутність технологічної та структурної модернізації, пріоритет сьогоднішніх заробітків над добробутом у майбутньому.

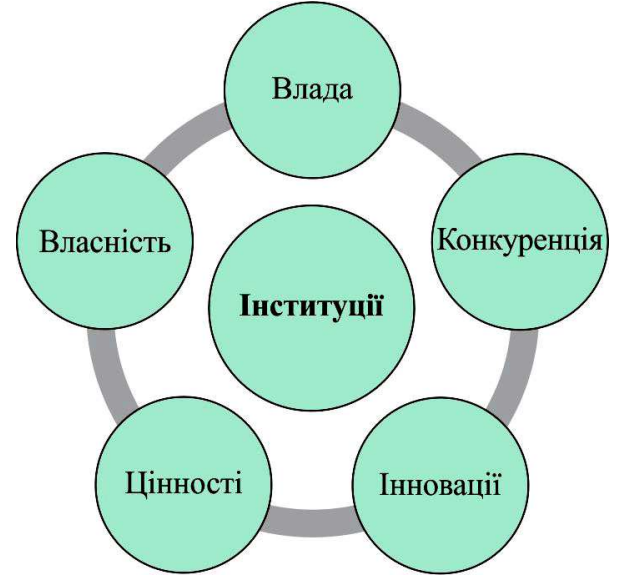

Рисунок. Авторський підхід до аналізу трансформаційних і еволюційних процесів в українській господарській системі [12]

Окрім цього, нерідко доходи від приватизації спрямовували на споживання й фінансування соціальної сфери, а інвестиційні видатки становили близько $6 \%$ від суми продажу основних фондів [9, с. 28]. Отже, вони використовувались не за призначенням і сприяли "проїданню" потенційних капіталовкладень та поступовій деградації інфраструктури. До того ж відповідні заходи щодо власності стосувались, власне, не іiі реформування, а формалізованої приватизації.

Відсутність єдиної бази даних щодо власності лише сприяла непрозорості і незрозумілості процесу для пересічних громадян та відкривала можливості для тіньових схем і корупції, особливо на етапі масової приватизації (1995-1999 рр.). Через формальні прорахунки він став періодом спекуляцій, втрати і незахищеності прав власності, зокрема міноритаріїв [14, с. 15]. Як відомо, понад 80 \% вартості об'єктів приватизації того часу перейшли у недержавну власність майже безплатно, за допомогою сертифікатів [4]. Поступово, через необізнаність і низьку активність населення та складну економічну ситуацію, ці багатства стали власністю колишніх представників бюрократії та майбутніх фінансово-промислових груп.

32000 р. реформування власності відбувається в більш індивідуальній формі, що в українських реаліях продовжило лінію непослідовної державної політики, створення політично інтегрованих компаній, реприватизації та асигнування збиткових держпідприємств. Незважаючи на окремі програми, спробу всеохопного підвищення ефективності державної власності після 2000 р. було зроблено тільки у 2015 р.

Йдеться про Стратегію підвищення ефективності суб'єктів державного сектору, котра має на меті покра- 
щити якість корпоративного управління, оздоровити державні банки, організувати прозорий відбір на керівні посади, розмежувати функції менеджменту та власності на держпідприємствах тощо. Внаслідок ухвалення Стратегії певні позитивні зміни відбулись та продовжують відбуватись. До прикладу, нову модель корпоративного управління запроваджено для НАК "Нафтогаз": розділено функції щодо транспортування і збереження газу, реформовано наглядову раду.

Окрім цього, вдалось досягнути співпраці уряду зі Світовим банком та СБРР щодо трансформації державних Укргазбанку та Ощадбанку, здійснено конкурсний відбір на керівні посади в "Укрпошті" та "Укрзалізниці" [14, с. 16-19]. Щодо розділення функцій управління та власності, ситуація більш неоднозначна 3 огляду на особливості інституційного співвідношення "влада власність" в українській економіці.

Негативним фактором, який з року в рік побутує в Україні, $є$ незаконні/нецільові витрати держпідприємств. Згідно із даними Державної аудиторської служби за 10 місяців 2019 р. [3, с. 7], такі витрати становили близько 700 млн грн і були пов'язані з необгрунтованим підвищенням посадових окладів або виплат підрядникам, списаннями коштів, збутом за заниженими цінами тощо. Як спостерігаємо, є спроби і результати державного реформування сфери власності, однак на цьому зупинятись не варто.

Далі сфокусуємо увагу на державній політиці реформування владних відносин. Зі здобуттям незалежності та ухваленням Конституції в Україні було утверджено президентсько-парламентську форму правління, котра формально проіснувала до 2004 р. За цей час президентські політичні інституції набули достатньо авторитарного жорсткого характеру. Незважаючи на те, що проведені стабілізаційні реформи допомогли створити базу для розвитку ринкових відносин в Україні, надалі вони постійно уповільнювались відповідно до компромісу із інтересами фінансово-промислових груп, позиції яких посилювались.

32004 р. політичний клімат дещо пом'якшився, оскільки влада набула парламентсько-президентської форми, проте через суперечності він знову повернувся до режиму пропрезидентської форми правління. Проіснувавши ще один цикл в межах такої моделі, українська господарська система у 2014 р. відновила парламентсько-президентську політичну структуру. Як бачимо, регулярні модифікації не створили достатнього інституційного грунту для довготермінового розвитку економіки та не дали змоги виробити послідовну дієву політику, а радше стали засобом задоволення інтересів зацікавлених груп та розпорошення ресурсів, зокрема часових.

Окрім цього, з огляду на змінювані умови, не вдалось провадити систематичну політику реформування державної служби, здійснення децентралізації та подолання корупції. Незважаючи на децентралізаційні тенденції, за останні роки спостерігаємо певні спроби до акумуляції влади на центральному рівні. Насамперед йдеться про відносну централізацію в умовах гібридної війни з Росією. Також маємо на увазі законопроект 2019 р. про внесення змін до Конституції щодо збільшення повноважень і посилення ролі президентської вертикалі, зокрема у питаннях впливу на органи місцевого самоврядування.
Як і багато інших реформ, трансформація сфери державного управління розпочалась ще у 1990-х роках. Попри десятки ухвалених документів у період з 1993 по 2016 pр., створення професійної держслужби відбувалось несистематично. Приблизно з 2010-х років державна політика стає структурованішою [11, с. 108, 109] - у формі довготермінової Стратегії та Закону "Про державну службу" у 2011-2012 рр., модернізації Національної академії державного управління та запровадження Національної рамки кваліфікацій.

Проте Революція гідності та прийняття нової стратегії у 2015-2016 рр. сукупно свідчать про те, що попередні результати не можемо вважати прийнятними. Згідно iз дослідженнями Vox Ukraine, на початку 2019 р. [1, с. 20-22], формальна реалізація оновленої реформи відбувалася досить цілеспрямовано: залучено 10 міністерств, організовано директорати як стратегічно-комунікаційні центри, запроваджено оновлені показники ефективності (зокрема, індивідуальні КРI), залучено нових позитивно зацікавлених індивідів, зроблено спробу перемістити акценти із ієрархічної вертикальної структури до роботи на підставі компетентності та співпраці.

Проте дослідники Vox Ukraine виявили i "побічні ефекти" трансформаційних зусиль. Серед них - певна протидія з боку чинного механізму державної служби та ризики створення корупційних схем у межах оновленої системи; інерція щодо роботи за старими підходами та правові труднощі щодо звільнення некомпетентних держслужбовців.

У сфері влади з 2014 р. активно відбувається ще одна дуже важлива реформа - децентралізація. Вона закріплена у змінах до Конституції (ст. 140) і Концепції реформування місцевого самоврядування та територіальної організації влади (2014р.). Згідно із даними сайту "Децентралізація в Україні" [2], ця реформа розпочалась досить вдало. Оновлено статті Бюджетного та Податкового кодексів, що дало змогу здійснити фінансову децентралізацію та досягти зростання локальних бюджетів 3 68,6 млрд грн у 2014 до 234 млрд грн у 2018 р.

Другий етап реформи (2019-2021) стосується закріплення провідної ролі громад, зростання їх кількості, удосконалення формальних правил, підтримки суміжних реформ охорони здоров'я, освіти, культури. До ризиків децентралізації належать слабша можливість держави впливати на прямий перерозподіл доходів між регіонами, втрата певного ефекту від масштабу, загрози локальних корупційних груп, а також повернення до централізації.

Від аналізу державного реформування владних відносин перейдемо до державної політики у сфері конкуренції. Її основи було закладено у 1993 р. Програмою демонополізації економіки і розвитку конкуренції. Незважаючи на регіонально-галузевий фокус програми, іï завдання не вдалось виконати вчасно, тому далі ухвалено ще цілу низку законів, програм та указів. Загалом, уряд та Антимонопольний комітет формально демонополізували економіку, але заходи із захисту конкуренції виявились не настільки ефективними, через що й спровокували нову хвилю монополізму. Вона виявилась у поступовому переважанні ринків з ознаками домінування та олігополій над конкурентними, а також поширенні політично інтегрованих компаній.

Головні сфери державної конкурентної політики також охоплюють питання наступного зменшення рівня 
монополізації, зростання конкурентоспроможності вітчизняних фірм, недопущення антиконкурентних владних практик. Попри задекларовані завдання та загальну пріоритетність конкурентної політики, з 2004 по 2014 рр. в Україні не було офіційного стратегічного документу щодо регулювання економічної конкуренції.

Тільки у 2012 р. схвалено Концепцію програми розвитку конкуренції в Україні на 2014-2024 роки. Вона наголосила на обмеженості конкурентного рівня та ефективності товарних ринків, недостатньо контрольованому зростанні цін, відносно низькому рівні продуктивності та інноваційності підприємств. Незважаючи на задекларовані у Концепції заходи [6], а також залучення громадянського суспільства, немає конкретних значень очікуваних результатів, а ринки з недосконалою конкуренцією за період з 2012 р. демонструють неоднозначну динаміку в бік зростання.

У Національній раді реформ в 2015 р. серед проблем також звернули увагу на "закляте коло" поєднання монополізованої влади на окремих ринках $з$ економічною владою шляхом акумуляції власності, а також значні масштаби монопольно-картельної ренти (за оцінками 2014-2015 pp., в середньому становили від 10 до $22 \%$ ВВП) [8, с. 3]. Для виконання Програми 2014-2024, Національна рада реформ зосередилась на питаннях захисту конкуренції (протидії змовам, контролю за державною допомогою, встановленням правил професійної етики тощо) та демонополізації (регулювання бар'єрів, реструктуризація природних монополій з особливими акцентами на ринках газу, ПЕК та житлово-комунального господарства).

Аналізуючи державний вплив на інституційне середовище, варто також звернути увагу на формування інноваційної політики. Програмотворча база для державного регулювання у цій сфері в різні періоди охоплювала Закон "Про пріоритетні напрями інноваційної діяльності в Україні" (2003, 2012), Концепцію науково-технологічного та інноваційного розвитку (1999), Державну цільову програму підтримки інноваційної інфраструктури (2008-2012, 2009-2013, 2017-2021) тощо. Загалом поставлених документами цілей не досягнуто, що свідчить про їх декларативний характер, а також непідготованість національної інноваційної системи до реалізації відповідних документів.

Формально офіційні "правила гри" гарантують податкові пільги для українських інноваційних підприємств (50 \% з суми/ставки податку на прибуток, земельного податку, ПДВ), а також митні пільги та прискорену амортизацію. На жаль, формальну дію відповідних положень призупинено, що означає фактичну відсутність дієвих стимулів для інноваційних підприємств (великою мірою, промислових) та висуває на порядок денний потребу перегляду відповідних пунктів законів.

Окрім цього, співфінансування інноваційної діяльності здійснюють у межах використання обмежених бюджетних коштів, питома вага яких у підтримці інноваційної діяльності підприємств становить близько 0,74,4 \% [7, с. 57], що насправді є мізерним для започаткування та підтримки інноваційного стрибка у вітчизняній економіці. Інша проблема полягає у нецільовому використанні коштів, котрі, з огляду на специфіку операційних проблем фірм, можуть використовуватись не на стимулювання інновацій.
Про загальну незацікавленість державних органів у створенні сприятливого інноваційного середовища свідчить затягування із обговоренням у 2009 р. та врешті неприйняття Стратегії інноваційного розвитку України 2010-2020 pp. Натомість було схвалено декларативну постанову Кабміну (2011 р.) із традиційними положеннями про пріоритет інноваційної економічної моделі, технологічну модернізацію та підвищення конкурентоспроможності економіки тощо. Загалом державна інноваційна політика (зокрема, у 2015-2017 рр.) функціонувала здебільшого шляхом вибіркової підтримки окремих галузей та проектів, що без дієвого загального грунту чинило досить обмежений позитивний вплив на економіку [5, с. 431].

Науковці впродовж тривалого часу наголошували на важливості прийняття всеохопної української стратегії інновацій (Стратегія-2030), і саме в 2019 р. це вдалось. Оскільки документ сформовано на підставі врахування формальних і неформальних факторів та думок різних "стейкхолдерів", маємо надію стосовно його майбутньої дієвості, особливо щодо створення повного циклу розроблення і впровадження інноваційних ідей.

3 огляду на раніше сформульовану автором п'ятикомпонентну інституційну структуру української економіки (котра охоплює сфери влади, власності, конкуренції, інновації та цінностей), маємо також звернути увагу на державні зусилля щодо впливу на формування цінностей. Звісно, головним двигуном у цій царині виступають неформальні норми, однак уряд певною мірою впливає на вектор їх розвитку. Насамперед йдеться про державну підтримку культури і освіти, втіленої у Законах "Про освіту" (1991, 2017) та "Про культуру" (2010).

Варто почати 3 того, що освіта у будь-якій державі $\epsilon$ показником розвитку суспільства, тому державне гарантування доступу до дошкільної, шкільної та вищої освіти є запорукою реалізації інтелектуальних здібностей і потреб людей. Близько 20 років з моменту проголошення незалежності українська освіта не зазнавала змін, а головними проблемами залишались незначна автономія навчальних закладів, нерезультативне державне фінансування (незважаючи на обсяги, орієнтація переважно на поточні витрати) та корупційні схеми [10]. 32010 р. освіта увійшла до пріоритетів програми економічних реформ 3 акцентами на вивченні іноземних мов, інформаційних технологій, перегляду пільг громадян тощо, однак з часом ця реформа відійшла на другий план.

У 2017-2019 pр. знову спостерігаємо активізацію державних регулювальних зусиль щодо освіти, сфокусованих передусім на середніх школах та посиленій дошкільній і початковій шкільній підготовці, ранньому розвитку, інклюзивній освіті, а також розширенні автономії навчальних закладів. Поряд з тим держава звертає увагу і на розвиток культури.

Державна політика регулювання культури в Україні спрямована на всебічну підтримку творчого потенціалу громадян, закладення національних спільних моральних цінностей, підтримку громадянського суспільства тощо. На жаль, через регулярні зміни зовнішньополітичного вектора та мотивацій владної верхівки з проавторитарної на продемократичну та навпаки, політика щодо культури (особливо мови) мала мінливий характер. Одним із показових моментів стало прийняття, а через кілька років відкликання Закону "Про засади дер- 
жавної мовної політики" (2012), котрий під прикриттям розширення прав регіональних мов (мов меншин) закладав політику подальшого розщеплення громадян за мовною ознакою.

Ясність у культурній галузі допомогла внести Революція Гідності, одним із продуктів якої стало прийняття Довготермінової стратегії розвитку української культури (2016), спрямованої на децентралізацію керівництва культурою, підтримку регіонального розвитку, національної ідентичності та міжкультурного діалогу. Насамперед, варто зазначити, що з 2016 р. уряд реалізує державну політику щодо введення мовних квот на телебаченні та радіо з метою більшої популяризації україномовного контенту. Важливою віхою та певним підсумком попередніх здобутків у сфері культури також стало набуття чинності закону "Про забезпечення функціонування української мови як державної" (2019).

Висновки. Підсумовуючи питання успішності вітчизняної державної політики щодо інституцій у межах авторського підходу, варто зазначити, що через стійкий симбіоз влади, власності, політично підтримуваного монополізму, популізму, непрозорості, незацікавленості у змінах/інноваціях, державна політика на багато років стала полем битви для інтересів вузьких груп, тоді як суспільні потреби не були на першому місці.

3 реальної практики бачимо, що така конфігурація в економіці та державній політиці вилилась у хронічну незавершеність реформ, їх гальмування при перших позитивних результатах або перешкодах. Попри загальну терплячість, українці прагнуть бачити задовільний результат державної економічної політики одразу, без очікувань, через що зростає попит на політиків-популістів, котрі в обмін на голоси пропонують виконання нереалістичних обіцянок.

Незважаючи на те, що в економіці зберігається "клімат" із недореформованими "правилами гри", котрими насправді невдоволені усі учасники процесу - індивіди, бізнес, влада, ніхто не прагне до кардинальної зміни системи інституцій. Суб'єкти вже пристосувались до такого стану речей та не впевнені, що наступні нововведення не погіршать ситуацію, а зацікавлені групи не бажають втрачати фаворитських позицій.

Оскільки така амбівалентність лише затримує вітчизняну економіку на тому ж рівні розвитку, державна політика щодо інституцій логічно має мати єдиний вектор - або зупинити реформування та посилити механізми екстракції (що тільки поверне Україну до іiї минулого), або ж свідомо ослабити її тиск на економіку та стратегічно рухатись в напрямку побудови інклюзивних політичних й економічних інституцій, що $є$ бажаним.

\section{References}

1. Bilous, A., \& Tyshchuk, T. (2019). Reforma derzhavnoi sluzhby v Ukraini: modeli uspikhu v reformuvanni instytutsii. Vox Ukraine, $40 \mathrm{p}$. [In Ukrainian].

2. Decentralization in Ukraine. (2020). Website Materials. Retrieved from: https://decentralization.gov.ua/. [In Ukrainian].

3. Derzhavna audytorska sluzhba Ukrainy. (2019). Zvit "Pro stan finansovo-biudzhetnoi dystsypliny pry vykorystanni biudzhetnykh koshtiv, derzhavnoho i komunalnoho maina". Informatsiia za rezultatamy u sichni-zhovtni 2019 roku. Retrieved from: http://dkrs.kmu.gov.ua/kru/doccatalog/document?id=155271. [In Ukrainian].

4. Fond Derzhavnoho Maina Ukrainy. (2016). Informatsiia shchodo reformuvannia vidnosyn vlasnosti v Ukraini za 2016 rik. Derzhavnyi informatsiynyi biuleten pro pryvatyzatsiyu. Retrieved from: http://www.spfu.gov.ua/userfiles/pdf/za-rik-2016 10331.pdf. [In Ukrainian].

5. Huseinov, T. T., \& Kulak, N. V. (2018) Derzhavne rehuliuvannia innovatsiinoho rozvytku pidpryiemnytskoi diialnosti v Ukraini. Materialy III Vseukrainskoi naukovoi konferentsii "Osvitno-innovatsiina interaktyvna platforma "Pidpryiemnytski initsiatyvy" 6 hrudnia 2018 roku, 428-435. [In Ukrainian].

6. Kabinet Ministriv Ukrainy. (2012). Pro skhvalennia Kontseptsii Zahalnoderzhavnoi prohramy rozvytku konkurentsii na 20142024 roky: rozporiadzhennia №690-2012 vid 17.12.2012. [In Ukrainian].

7. Malinina, N. M., \& Prychepa, I. V. (2018) Problemy ta perspektyvy derzhavnoho rehuliuvannia innovatsiinoho rozvytku vitchyznianykh pidpryiemstv. Investytsii: praktyka ta dosvid, 12, 53-58. [In Ukrainian].

8. Natsionalna rada reform. (2015). Zavdannia konkurentnoi polityky v konteksti ekonomichnych reform. NRR, 12 p. [In Ukrainian].

9. Nohinova, N. M. (2014) Transformatsiia form vlasnosti v Ukraini: problemy i priorytety. Naukovi zapysky Natsionalnoho universytetu "Ostrozka Academia". Seria "Ekonomika", 27, 27-30. [In Ukrainian].

10. Orlova, I. (2013) Reforma osvity v Ukraini. Open Society Foundations Proekt "Populiarna ekonomika: monitorynh reform". Retrieved from: https://eba.com.ua/static/members reviews/Case Study 17 02 2013 UKR. [In Ukrainian].

11. Pryhorodova, S. (2012) Reforma derzhavnoi sluzhby yak skladova administratyvnoi reformy v Ukraini. Visnyk Natsionalnoi akademii derzhavnoho upravlinnia, 4, 103-113. [In Ukrainian].

12. Salovskyi, O. B. (2020) Transformatsiia ukrainskoi hospodarskoi systemy u rozrizi instytutsiy vlasnosti, vlady, konkurentsii, innovatsiy ta tsinnostei. Visnyk Lvivskoho universytetu. Seriia Ekonomichna, 1(57), 271-281. [In Ukrainian].

13. Savchenko, V. F. (2015) Derzhavne rehuliuvannia vidnosyn vlasnosti u rynkoviy ekonomitsi. Naukovyi visnyk Polissia, 3(3), 918. [In Ukrainian].

14. Zakharchenko, V. I. (2018) Reforma upravlinnia derzhavnoiu vlasnistiu yak osnova reformuvannia vidnosyn vlasnosti v Ukraini. Visnyk Cherkaskoho universytetu, 1, 14-24. [In Ukrainian].

\section{O. B. Salovskyi \\ Ivan Franko National University of Lviv, Lviv, Ukraine}

\section{PUBLIC POLICY REFORMS OF INSTITUTIONS SYSTEM IN UKRAINE}

The article explores the peculiarities of economic reforms in Ukraine from an institutionalist viewpoint. Based on a previously developed author's approach to analyzing the evolution of Ukraine's economic system, the paper seeks to investigate the institutional roots of relatively ineffective or semi-finished reforms in the realms of property, power, competition, innovations, and values. At first, it reveals the situation with property reforms starting from the privatization outset and active development in the $1990 \mathrm{~s}$, inconsiderate property policy in the $2000 \mathrm{~s}$, as well as new challenges and promising moments from the contemporary period, e.g. efforts aimed at increasing the efficiency of state firms starting from 2015. Secondly, the article examines the nature of power relations in the Ukrainian economy. Due to regular transitions from a president-parliamentary to a premier-presidential form of political organization, the system did not create a firm institutional basis for long-term economic development and a systematic policy of civil servi- 
ce and corruption combat, however attaining first decent results in power decentralization. Moreover, the paper focuses on outlining the institutional specifics of the state competition policy in Ukraine. Despite initially approved protection norms, which later proved ineffective, the government lacked a corresponding competition strategy for decades, with a respective share of competitive markets decreasing. In turn, it spurred the emergence of the expected strategy and a new set of anti-monopoly measures. Besides, the publication considers the influence of public policy efforts on innovative activity in the Ukrainian economy, as well as on society values, education, and culture, which tend to not actively foster stable and considerate attitude towards change, innovations and new ideas. As a result of a negative combination of power and property, dominated by oligarchic industrial-financial groups, politically supported monopolism, populism, lack of transparency, low interest in innovations, public policy for many years resembled a battleground for special interest groups. Consequently, the needs of the society occupied a secondary place, which translated into commonly unfinished or prolonged public reforms. Since this ambiguity only hinders Ukrainian economy from further development, the country leaders have to concentrate on decreasing the amount of economic rent extraction and augmenting the growth of inclusive political and economic institutions.

Keywords: formal insitutions; institutional reforms; property; power; competition; innovations; values. 